\title{
Bioturbation at the water-sediment interface of the Thau Lagoon: impact of shellfish farming ${ }^{\star}$
}

\author{
Sabine Schmidt ${ }^{1, a}$, Jean-Louis Gonzalez ${ }^{2}$, Pascal Lecroart ${ }^{1}$, Jacek Tronczyñski ${ }^{3}$, Isabelle Billy ${ }^{1}$ and \\ Jean-Marie Jouanneau ${ }^{1}$ \\ CNRS-Université Bordeaux, UMR5805 EPOC, avenue des Facultés, 33405 Talence, France \\ 2 IFREMER, LBCM, BP 330, Zone portuaire de Brégaillon, 83507 La Seyne-sur-Mer Cedex, France \\ ${ }^{3}$ IFREMER, LBCO, BP 21105, 44311 Nantes Cedex, France
}

Received 2 October 2006; Accepted 12 June 2007

\begin{abstract}
Quantifying of sediment reworking processes provides new insights into benthic ecosystem functioning of the Thau lagoon, an important European shellfish farming area. In order to evaluate bioturbation rates of surface sediments, profiles of ${ }^{7} \mathrm{Be}$ (half-life: 53 days) and ${ }^{234} \mathrm{Th}$ (half-life: 24.1 days) were measured in cores collected since December 2001 to December 2006. Several sites were selected to sample the diversity of the Thau lagoon: C4, T10, and T11 in the middle of the lagoon, C5, T7 and T8 nearby oyster farming, T2 and T4 in the western edge, T12 in the eastern part closed to industry. ${ }^{234} \mathrm{Th}$ in excess $\left({ }^{234} \mathrm{Th}_{x s}\right.$; i.e. supplied to sediment by settling particles) and ${ }^{7}$ Be both show seasonal variations in activities and in penetration within sediment. Taking into account the moderate sedimentation rates of the Thau lagoon, sites $(0.1-0.4 \mathrm{~cm}$ per year), the penetration of both short-lived radionuclides to variable depths, from 1 up to $8 \mathrm{~cm}$, indicates efficient biological mixing of upper sediments. Bioturbation rates $\left(D_{\mathrm{b}}\right)$ to the distribution of excess ${ }^{234} \mathrm{Th}\left({ }^{234} \mathrm{~Pb}-D_{\mathrm{b}}\right)$ and of ${ }^{7} \mathrm{Be}\left({ }^{7} \mathrm{Be}-D_{\mathrm{b}}\right)$ range between 1 and $35 \mathrm{~cm}^{2} \mathrm{y}^{-1}$, depending on site and season. Surface sediment mixing of the Thau lagoon is primarily controlled by the quality of particle input, i.e. the food supply to the benthic fauna, mainly governed by the hydrological and seasonal conditions. But locally shellfish production is a key parameter that influences bioturbation through biodeposition.
\end{abstract}

Key words: Sedimentation / Biodeposition / Radionuclides / Mediterranean Lagoon

Résumé - Bioturbation à l'interface eau-sédiment de l'étang de Thau : impact des activités ostréicoles. Quantifier les processus de remaniement sédimentaire procure une vision nouvelle du fonctionnement des écosystèmes benthiques de l'étang de Thau, lieu d'une importante production ostréicole. Afin d'évaluer les taux de bioturbation des sédiments de surface, des profils de deux traceurs radioactifs, le béryllium ${ }^{7} \mathrm{Be}\left(\mathrm{T}_{1 / 2}=53\right.$ jours $)$ et le thorium ${ }^{234} \mathrm{Th}\left(\mathrm{T}_{1 / 2}=24.1\right.$ jours$)$ ont été mesurés à partir de carottes sédimentaires prélevées entre décembre 2001 et décembre 2006. La sélection de plusieurs sites a permis de couvrir la diversité de l'étang de Thau : C4, T10, et T11 dans le bassin central, C5, T7 et T8 au niveau des secteurs ostréicoles, T2 et T4 à l'ouest du bassin, et T12 à l'est près de la zone industrielle. Le ${ }^{234} \mathrm{Th}$ en excès $\left({ }^{234} \mathrm{Th}_{x s}\right.$; i.e. apporté au sédiment par la sédimentation des particules) et le ${ }^{7}$ Be présentent des variations saisonnières de leurs activités et de leurs pénétrations dans le sédiment. Compte tenu des faibles taux de sédimentation reportés pour l'étang de Thau $(0.1-0.4 \mathrm{~cm}$ par an), la pénétration à des profondeurs variables (de 1 à $8 \mathrm{~cm}$ ) des deux radioéléments à courte durée de vie révèle un mélange efficace des sédiments superficiels en lien avec l'activité biologique. Les taux de bioturbation $\left(D_{\mathrm{b}}\right)$ calculés au moyen des profils de ${ }^{234}$ Th en excès $\left({ }^{234} \mathrm{Th}-D_{\mathrm{b}}\right)$ et de ${ }^{7} \mathrm{Be}\left({ }^{7} \mathrm{Be}-D_{\mathrm{b}}\right)$ sont compris entre $<1$ et $35 \mathrm{~cm}^{2} \mathrm{an}^{-1}$, selon les sites et la saison considérés. Le mélange des sédiments d'interface de l'étang de Thau apparait principalement contrôlé par la qualité du flux de particules, apport de nourriture pour la faune benthique, en lien avec l'hydrologie et les saisons. Localement, l'activité ostréicole est le facteur prépondérant qui influence la bioturbation via les biodépôts.

\section{Introduction}

The Mediterranean Thau Lagoon (France, $3^{\circ} 36^{\prime}$ E, $43^{\circ} 24^{\prime} \mathrm{N}$ ) is located on French southern coast (Fig. 1). With

* This paper belongs to a PNEC series of articles published in Aquatic Living Resources Vol. 20, No. 1, 2007.

a Corresponding author: s.schmidt@epoc.u-bordeaux1.fr a surface area of about $75 \mathrm{~km}^{2}$ and a mean depth of $5 \mathrm{~m}$, this shallow basin is connected to the Mediterranean Sea by three narrow channels. This rich coastal lagoon system including its watershed is subject to major human pressure: oyster and mussel culture fisheries, tourism, urbanism development, wineyards etc. (Labonne et al. 2001; Plus et al. 2001). In addition to its ecological importance as a recruitment zone 
for some sea fish species, the Thau lagoon is an important European shellfish farming area for both Japanese oysters (Crassostrea gigas) and Mediterranean mussels (Mytilus galloprovincialis). With a standing stocks of Crassostrea gigas estimated at 40000 tons, it is now the fourth French site of shellfish cultivation, i.e. roughly $10 \%$ of the national production, with about 15000 tons of oysters and nearly 4000 tons of mussels per year (Dupuy et al. 2000; Gangnery et al. 2001). Hence shellfish farming may interact with the other components of the Thau Lagoon and exercise a major influence on this fragile ecosystem. This situation has led to a large number of scientific studies to determine the impact of shellfish farming. Most of investigations consider the biological aspect (standing crop, population dynamics). Quantifying of sediment reworking processes is an alternative approach to investigate ecosystem functioning (Demopoulos et al. 2003; Maire et al. 2006). The ability of the benthic community to mix sediment depends on the type of organism, its density and its activity. Sediment mixing can also cause major changes to sediment, affecting in particular the diagenesis of organic matter and the distribution of recently deposited contaminants. Documenting how bioturbation vary temporally and spatially is critical to determine the overall health of a coastal ecosystem.

In this paper, we present an investigation of the bioturbation at the water-sediment interface of the Thau Lagoon. Results are based on detailed depth profiles of two short-lived radionuclides, ${ }^{234} \mathrm{Th}$ (24.1 days) and ${ }^{7} \mathrm{Be}$ (53 days), along with granulometry determination, in sediment cores collected at different seasons between 2001 and 2006. These data are interpreted in order to provide bioturbation rates $\left(D_{\mathrm{b}}\right)$ of surface sediments. This implemented time-series provides the opportunity to address specific questions: (1) is there a spatial variability of bioturbation (2) how this could be related to the characteristics of this basin (hydrodynamic, shellfish production). The discussion encompasses the present work and a synthesis of recently published articles to infer the potential impact of the shellfish farming at the water-sediment interface of the Thau lagoon.

\section{Materials and methods}

\subsection{Field and laboratory methods}

Repeated field campaigns allowed to sample the watersediment interface of the Thau Lagoon at selected sites throughout the basin. The first phase of this work (PNEC Microbent; 2001-2003) was focused on two sites: C4 in the central part of the basin and $\mathrm{C} 5$ in the shellfish production area (Fig. 1). The second phase (2003-2006, PNEC Chantier Lagunes méditerranéennes) encompassed the entire Thau Lagoon by sampling along a basin-wide transect, from east to west: T12, T11, T10, T8, T7, C4, T5, T4, T2, in May and June 2004, November 2005 and December 2006.

Scuba divers recovered sediment cores, less to $20 \mathrm{~cm}$ in length, by using hand-driven tubes. Immediately after core retrieval, cores were carefully sliced each $1 / 2 \mathrm{~cm}$ by upward extrusion. Back to the lab, sediment samples were sieved at $63 \mu \mathrm{m}$ and dried at $60{ }^{\circ} \mathrm{C}$. Then the uppermost sediment layers were measured for ${ }^{234} \mathrm{Th}$ and ${ }^{7} \mathrm{Be}$ determinations using a low background-high efficiency well type $\gamma$-detector and a semiplanar germanium detector (Schmidt et al. 2002). Standards used for the calibration of the $\gamma$ detectors are International Atomic Energy Agency (IAEA) standards (RGU-1, RGTh-1, IAEA-375). These measurements had to be completed within one month after sampling, due to the rapid decay of ${ }^{234} \mathrm{Th}$. Sediment layers were investigated downcore until the disappearance of ${ }^{7} \mathrm{Be}$ and a rather constant ${ }^{234} \mathrm{Th}$ activity was reached, which was considered as the supported activity. ${ }^{238} \mathrm{U}$ activities were determined by $\alpha$ counting after sediment digestion by a mixture of $\mathrm{HF}-\mathrm{HNO}_{3}-\mathrm{HClO}_{4}$ in presence of ${ }^{232} \mathrm{U}$ (Schmidt and Reyss 2000).

Excess ${ }^{234}$ Th data were calculated by subtracting the activity supported by its parent isotope, ${ }^{238} \mathrm{U}$, from the total activity in the sediment. Both ${ }^{234} \mathrm{Th}_{x s}$ and ${ }^{7} \mathrm{Be}$ activities were corrected for radioactive decay that occurred between sample collection and counting.

\subsection{Bioturbation model}

Neglecting non-local mixing, excess ${ }^{234} \mathrm{Th}$ and ${ }^{7} \mathrm{Be}$ profiles are determined by diffusive bioturbation, sediment accumulation rate and radioactive decay (Boudreau 1997):

$$
\frac{\partial A}{\partial t}=D_{\mathrm{b}} \frac{\partial^{2} A}{\partial z^{2}}-S \frac{\partial A}{\partial z}-\lambda A
$$

where $A$ is the activity $\left(\mathrm{mBq} \mathrm{g}^{-1}\right)$ of ${ }^{7} \mathrm{Be}$ or excess ${ }^{234} \mathrm{Th}, z$ is the depth into the sediment $(\mathrm{cm}), D_{\mathrm{b}}$ is the vertical biodiffusion, or bioturbation, coefficient $\left(\mathrm{cm}^{2} \mathrm{y}^{-1}\right), S$ is the sedimentation rate $\left(\mathrm{cm} \mathrm{y}^{-1}\right)$, and $\lambda$ is the decay constant of the considered radionuclide $\left(\mathrm{y}^{-1}\right)$. The simplest way to derive $D_{\mathrm{b}}$ from radionuclide profiles using Eq. (1) is to assume steady state and negligible sedimentation accumulation. The steady state approximation, often used to derive bioturbation rates from radionuclide profiles, introduces only limited errors (Lecroart et al. 2007a). The latter simplification supposed to respect the inequality: $S^{2} \ll 4 D_{\mathrm{b}} \lambda$ (Wheatcroft 2006). Sedimentation rates of the Thau Lagoon are always lower to $0.4 \mathrm{~cm} \mathrm{y}^{-1}$ (Monna et al. 1997); sedimentation rates for sites C4 and C5, investigated during the first phase of this work, are about 0.25 and $0.15 \mathrm{~cm} \mathrm{y}^{-1}$ (Schmidt et al. 2007). Thus one can assume that sediment accumulation rates are not likely to affect shortlived radionuclides profiles.

These simplifications allow to determine bioturbation rates from a simple plot of radionuclide activity as a function of depth, using (2):

$$
A=A_{0} \exp \left(-z \sqrt{\frac{\lambda}{D_{\mathrm{b}}}}\right)
$$

where $A_{0}$ is the activity $\left(\mathrm{mBq} \mathrm{g}^{-1}\right)$ of ${ }^{7} \mathrm{Be}$ or excess ${ }^{234} \mathrm{Th}$ at the water-sediment interface (Schmidt et al. 2001). This method was applied to profiles of ${ }^{234} \mathrm{Th}_{x s}$ and ${ }^{7} \mathrm{Be}$ of the Thau Lagoon to calculate bioturbation coefficients $D_{\mathrm{b}}$ (Table 1 ).

\section{Results}

A total of 41 cores were analyzed for short-lived radionuclides from 2001 to 2006 throughout the Thau Lagoon (Fig. 1). 


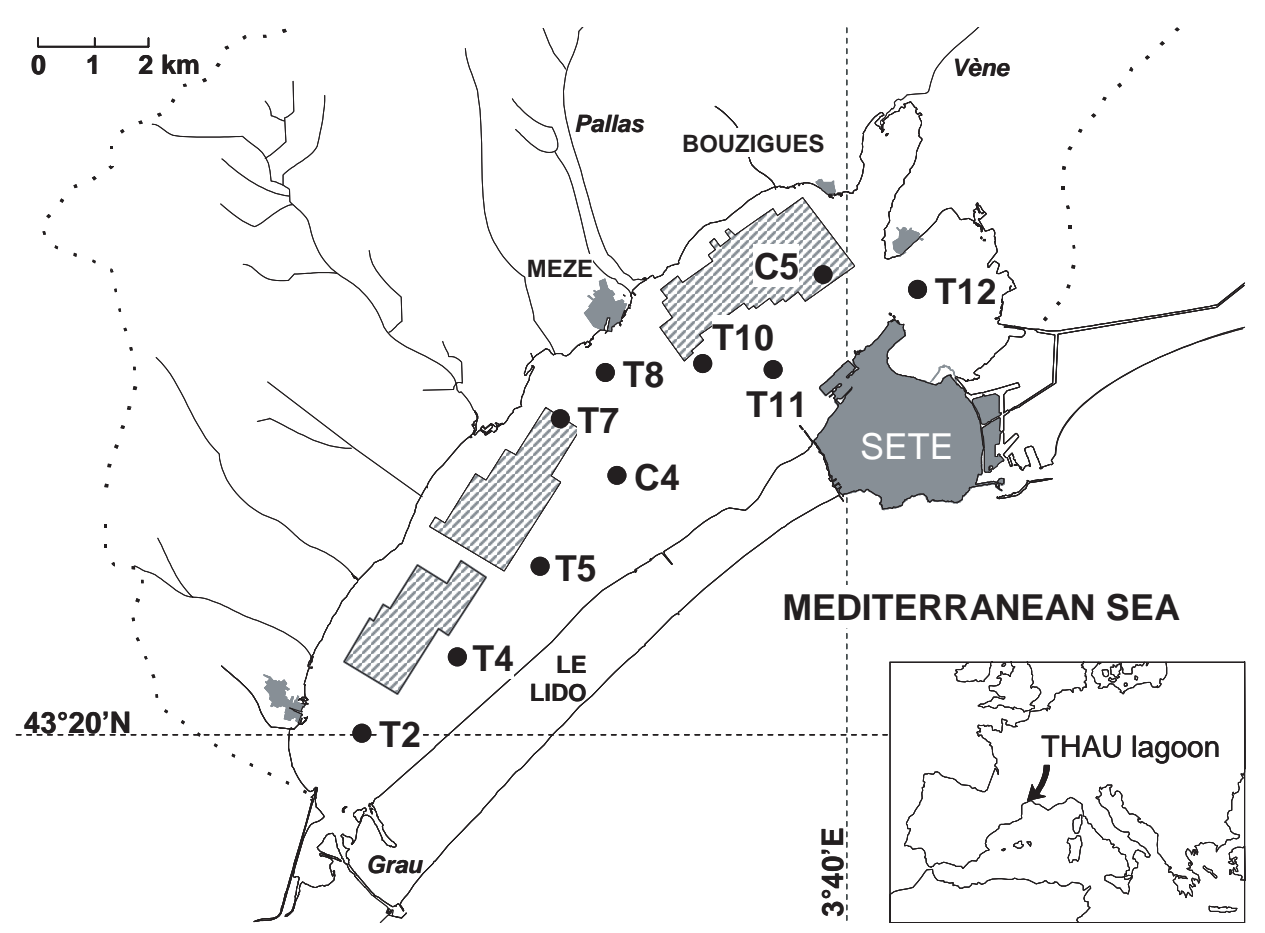

Fig. 1. Map of the Thau lagoon showing the locations of the sampling stations. The dashed areas encompass the locations of shellfish farming.

Table 1. Bioturbation coefficients derived from ${ }^{7} \mathrm{Be}$ and ${ }^{234} \mathrm{Th}_{x s}$ profiles in surface sediments of the Thau Lagoon.

\begin{tabular}{|c|c|c|c|c|c|c|c|}
\hline Date & Core & $\begin{array}{c}{ }^{7} \mathbf{B e}-D_{\mathrm{b}} \\
\left(\mathbf{c m}^{2} \mathbf{y}^{-1}\right) \\
\end{array}$ & $\begin{array}{r}{ }^{234} \mathbf{T h}-D_{\mathrm{b}} \\
\left(\mathbf{c m}^{2} \mathbf{y}^{-1}\right) \\
\end{array}$ & Date & Core & $\begin{array}{c}{ }^{7} \mathbf{B e}-D_{\mathrm{b}} \\
\left(\mathbf{c m}^{2} \mathbf{y}^{-1}\right) \\
\end{array}$ & $\begin{array}{l}{ }^{234} \mathbf{T h}-D_{\mathrm{b}} \\
\left(\mathbf{c m}^{2} \mathbf{y}^{-1}\right) \\
\end{array}$ \\
\hline \multicolumn{4}{|c|}{ Site C4 } & \multicolumn{4}{|c|}{ Site C5 } \\
\hline Dec. 4, 2001 & C4-1 & 3.0 & n.d. & Dec. 4, 2001 & C5-1 & 5.0 & n.d. \\
\hline Dec. 4, 2001 & $\mathrm{C} 4-2$ & 1.3 & 3.5 & & & & \\
\hline Dec. 4, 2001 & $\mathrm{C} 4-3$ & 4.0 & 1.6 & & & & \\
\hline \multirow{3}{*}{ April 10, 2002} & C4-4 & 1.6 & 4.6 & April 9, 2002 & $\mathrm{C} 5-3$ & 3.4 & 2.8 \\
\hline & $\mathrm{C} 4-5$ & n.d. & 1.9 & & $\mathrm{C} 5-4$ & 1.1 & 3.6 \\
\hline & C4-6 & 1.5 & 2.4 & & $\mathrm{C} 5-5$ & 6.1 & 7.9 \\
\hline July 17,2002 & C4-7 & 8.2 & 10.8 & July 17,2002 & C5-6 & 30.0 & 31.8 \\
\hline \multirow[t]{2}{*}{ Aug. 27, 2002} & $\mathrm{C} 4-8$ & 4.4 & 7.7 & Aug. 28, 2002 & $\mathrm{C} 5-7$ & 12.0 & 1.2 \\
\hline & C4-9 & 3.5 & 10.7 & & $\mathrm{C} 5-8$ & 7.7 & 3.8 \\
\hline Jan. 28, 2003 & C4-10 & 3.4 & n.d. & Jan. 28, 2003 & $\mathrm{C5}-9$ & 3.4 & n.d. \\
\hline \multirow{2}{*}{ May 19, 2003} & C4-11 & 6.3 & 6.9 & May 20, 2003 & C5-10 & 2.7 & n.d. \\
\hline & $\mathrm{C} 4-12$ & 4.5 & 2.3 & & C5-11 & 1.0 & n.d. \\
\hline \multirow[t]{3}{*}{ June 22, 2004} & C4-13 & 11.7 & 16.7 & June 22, 2004 & C5-12 & 0.9 & 1.8 \\
\hline & C4-14 & n.d. & 7.4 & & C5-13 & 2.3 & 8.5 \\
\hline & & & & & C5-14 & 19.6 & 5.8 \\
\hline Nov. 15,2005 & C4-15 & 0.4 & $<1$ & & & & \\
\hline \multirow[t]{3}{*}{ May 5-6, 2004} & $\mathrm{~T} 2$ & 1 & n.d & Dec. 6, 2006 & $\mathrm{~T} 2$ & $<1$ & $<1$ \\
\hline & T5 & 7.1 & n.d & & $\mathrm{T} 7$ & $<1$ & $<1$ \\
\hline & $\mathrm{T} 12$ & 1.9 & 5.2 & & $\mathrm{~T} 8$ & $<1$ & $<1$ \\
\hline \multirow[t]{5}{*}{ Nov. 15-19, 2005} & $\mathrm{~T} 2$ & 0.6 & $<1$ & & $\mathrm{~T} 10$ & $<1$ & $<1$ \\
\hline & $\mathrm{T} 4$ & 0.5 & 0.7 & & $\mathrm{~T} 12$ & $<1$ & $<1$ \\
\hline & T5 & 2.8 & 0.7 & & & & \\
\hline & $\mathrm{T} 11$ & 6.3 & n.d. & & & & \\
\hline & $\mathrm{T} 12$ & 1.5 & 1.2 & & & & \\
\hline
\end{tabular}

n.d.: too low levels of ${ }^{234} \mathrm{Th}_{x s}$ or ${ }^{7} \mathrm{Be}$

When ${ }^{234} \mathrm{Th}_{x s}$ or ${ }^{7} \mathrm{Be}$ were detected only in the uppermost layer, a maximum value of $1 \mathrm{~cm}^{2} \mathrm{y}^{-1}$ is assumed. 


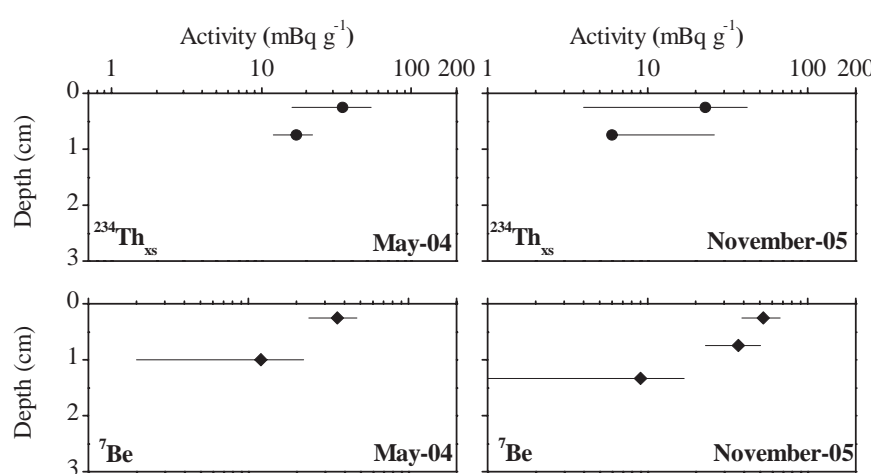

Fig. 2. ${ }^{7} \mathrm{Be}$ and ${ }^{234} \mathrm{Th}_{x s}$ with depth in the sediment: example of site 12 in May 2004 (left panel) and November 2005 (right panel).

Both ${ }^{234} \mathrm{Th}$ and ${ }^{7} \mathrm{Be}$ show marked variations in activities and in penetration within the sediment (Fig. 2). When collected, replicate cores show a rather good reproducibility.

Along the east-west transect (sites T12, T11, C4, T5, T4, $\mathrm{T} 2$ ), uppermost activities of ${ }^{234} \mathrm{Th}_{x s}$ and ${ }^{7} \mathrm{Be}$ are comprised between negligible values and $180 \mathrm{mBq} \mathrm{g}^{-1}$. Except for site C5, both radionuclides are never measured deeper than $2 \mathrm{~cm}$. Even, for few cores activities were restricted to the uppermost layer, or even too negligible to be detected. In December 2006, ${ }^{234} \mathrm{Th}_{x s}$ and ${ }^{7} \mathrm{Be}$ were only measurable in the uppermost layer of sediment whatever the considered site (T2, T7, T8, T10, T12). Lowest levels and penetration depth are usually observed in the western basin (T2, T4) and throughout the whole basin in winter conditions. Site C5 displays a singular pattern with the highest penetration depths, up to $8 \mathrm{~cm}$ for ${ }^{7} \mathrm{Be}$ in July 2002 .

Considering the short half-life of the considered radionuclides and the mean sedimentation rate of the Thau Lagoon $\left(0.2-0.3 \mathrm{~cm} \mathrm{y}^{-1}\right)$, the penetration of ${ }^{234} \mathrm{Th}_{x s}$ and ${ }^{7} \mathrm{Be}$, usually within the 3 first $\mathrm{cm}$, confirms the occurrence of an efficient mixing of the surface sediment. All profiles of these two radionuclides are well fitted by regression line, indicating that sediment mixing processes are described by eddy diffusion and justifying the choice of the bioturbation model described in Sect. 2.2. Bioturbation rates derived from the Eq. (2) are in the lower range of published values for coastal environment (Aller et Cochran 1976; Fuller et al. 1999; Crusius et al. 2004; Widdows et al. 2004; Wheatcroft 2006). Cores sampled in December 2006 had very low surface activities and penetration depths of ${ }^{234} \mathrm{Th}_{x s}$ and ${ }^{7} \mathrm{Be}$ : a maximum value of $1 \mathrm{~cm}^{2} \mathrm{y}^{-1}$ was assumed (Table 1).

\section{Discussion}

\subsection{Are short-lived radionuclides appropriate to assess seasonal bioturbation in coastal systems?}

Quantifying of sediment reworking processes is an alternative approach to investigate ecosystem functioning. The most common approach to quantify bioturbation intensity is to consider the vertical distribution of solid phase tracers, such as particle-bound radionuclides (e.g. ${ }^{210} \mathrm{~Pb},{ }^{234} \mathrm{Th}$,
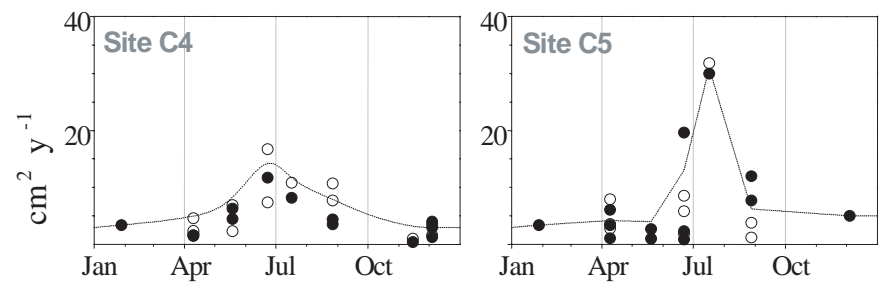

Fig. 3. Composite yearly evolution of bioturbation rates, derived from ${ }^{7} \mathrm{Be}$ (dark circle) and ${ }^{234} \mathrm{Th}_{x s}$ (open circle), at the water-sediment interface of sites: C4 and C5 (2001, 2002, 2003, 2004, 2005).

${ }^{7}$ Be; Schmidt et al. 2001) or introduced particles (e.g. luminophores, Duport et al. 2007). Recently, using a latticeautomaton model of bioturbation, Reed et al. (2006) suggested that the time scales of short-lived radioisotopes, such as ${ }^{234} \mathrm{Th}$ and ${ }^{7} \mathrm{Be}$, are insufficient for the tracers to be used with the biodiffusion model. This study was not based on systematic tests concerning the different parameters $(\lambda$ : the decay rate of considered radionuclide; $D_{\mathrm{b}} ; L$, the thickness of the mixed layer) that control the system, and the above conclusions are biased. Using a new global compilation of radionuclide data in marine sediments, extensive numerical tests of seasonal sensitivity indicate that ${ }^{234} \mathrm{Th}$ and ${ }^{7} \mathrm{Be}$ are, in fact, the most sensitive tracers to seasonal biological mixing in most sedimentary environment (Lecroart et al. 2007b). In addition this study reveals ${ }^{234} \mathrm{Th}$ to be the more sensitive tracer to detect seasonal biological mixing. Therefore the two short-lived tracers, ${ }^{234} \mathrm{Th}$ and ${ }^{7} \mathrm{Be}$, are particularly appropriate to coastal systems, where usually ${ }^{210} \mathrm{~Pb}$ presents a mixed layer. The present dataset is a clear illustration of the interest of this approach.

\subsection{Trends in bioturbation rates throughout the Thau lagoon}

The first phase of this work was focused on two contrasted sites: C4 in the central part of the Thau Lagoon and C5 in the shellfish production area. This first set of ${ }^{234} \mathrm{Th}$ and ${ }^{7} \mathrm{Be}$ profiles seemed to discern a probable seasonal signal in bioturbation intensity of Thau surface sediments (Schmidt et al. 2007). Additional samplings in May and June 2004, November 2005 and December 2006, allowed to establish a more complete picture of the annual variations (Fig. 3). This implemented timeseries for sites C4 and C5 clearly highlights marked variations in bioturbation throughout year. In winter, bioturbation coefficients are always low, less to $5 \mathrm{~cm}^{2} \mathrm{y}^{-1}$; thereafter there is a gradual increase of mixing intensity to maximum levels (up to $35 \mathrm{~cm}^{2} \mathrm{y}^{-1}$ ) in summer followed by the decrease to background values.

When considering the entire basin, one could observe the same trend. When available, the comparison of winter to summer situations shows that bioturbation intensities are always higher in summer regardless of the site (Fig. 4). Nonetheless, there are notable differences among sites (Table 1). 


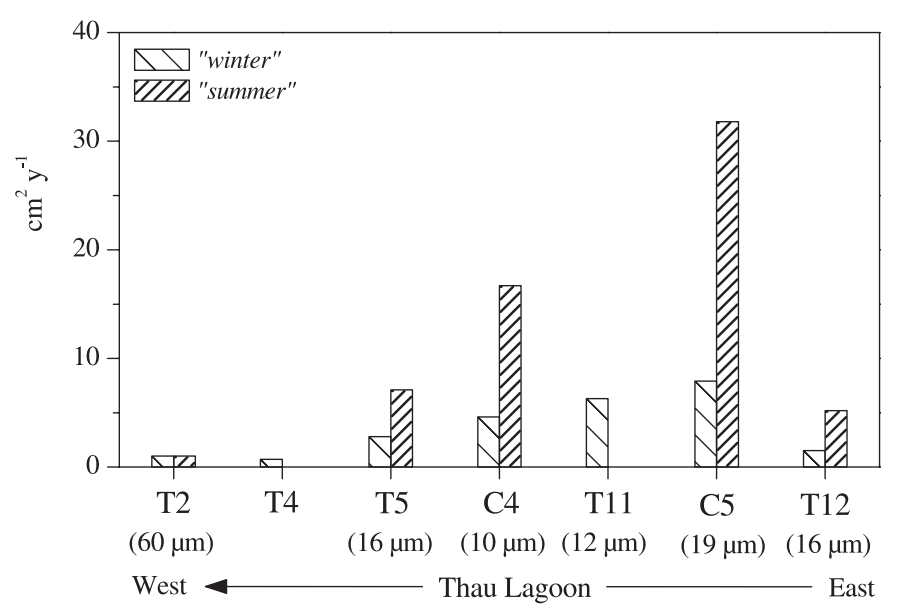

Fig. 4. Westward distribution of bioturbation rates at the watersediment interface of the Thau Lagoon. Bars (see legend) correspond to the range of bioturbation rates values, regardless of radionuclides, plotted for each site considering two main periods: "winter" (November to April) and "summer" (May to September) (Table 1). In brackets below site label: mean 0-2 cm surface sediment granulometry.

\subsection{Influence of hydrodynamic and shellfish farming on bioturbation}

Up to date, there are only scarce time-series of bioturbation intensities in marine sediments (Schmidt et al. 2002; Widdows et al. 2004; Wheatcroft 2006 and references herein). A common finding is the high level of variability in mixing intensity either spatially or temporally. The controlling factors the most frequently proposed are: benthic community (abundance, size), bottom-water temperature and food supply. For the Thau Lagoon, there is no strong relationship between benthic fauna and biodiffusive mixing (Duport et al. 2007). The second parameter, the bottom temperature, is likely to significantly affect animal activities. Temperatures of the Thau Lagoon vary seasonally from about 8 to $25{ }^{\circ} \mathrm{C}$ (Duport et al. 2007). But in such a shallow and small basin, there is no significant difference in bottom temperature between sites. Despite this homogeneity in bottom temperature, there is a large range in bioturbation rates (Fig. 4). Therefore bottom temperature is clearly not the parameter that could influence bioturbation in the Thau Lagoon.

The more probable parameter is the organic carbon flux. Although still discussed, evidences of impact of food supply on bioturbation intensity are increasing (DeMaster et al. 1994; Trauth et al. 1997 Schmidt et al. 2001; Smith and Rabouille 2002; Demopoulos et al. 2004). Direct measurements of particle and carbon organic fluxes are not available for the Thau Lagoon. However, indirect indications may be obtained by considering sediment accumulation pattern of this basin. Spatial distributions of bottom stress, of fine fraction $(<63 \mu \mathrm{m})$ in surface sediments and of sedimentation rates clearly point out the central part of the Thau Lagoon (sites C4, T11) as the preferential site for sedimentation (Monna et al. 1997; Schmidt et al. 2007). These high sedimentation rates could be in particular explained by winnowing effect, a process that involves resuspension by near-bed currents and subsequent lateral transport of fine-grained sediments from border sites to central part (Monna et al. 1997).

This winnowing effect, due to bottom current, may account for the low bioturbation rates observed for sites T2 and T4 on the western border of the Thau Lagoon. These sites are away from potential river discharges and do not appear as favorable sites for particle sedimentation. As a result, one could speculate that particle fluxes are low, justifying the low bioturbation intensities reported for sites $\mathrm{T} 2$ and $\mathrm{T} 4$, whatever the season (Fig. 4). Conversely, sites C4 and T11 are the counterpart of the two western sites: these central sites are the preferential loci of fine particle sedimentation. But old and low carbon particles, resulting from winnowing, may contribute for these fluxes. This could explain the occurrence of a weaker seasonal signal in bioturbation intensity, when compared to site C5.

For site C5, bioturbation rates show a strong seasonal signal (Fig. 3) with significantly higher values in summer (Fig. 4). In addition, during the first sampling phase (2001-2003), calculated ${ }^{234} \mathrm{Th}_{x s}$ and ${ }^{7} \mathrm{Be}$ fluxes at the water-sediment interface had exhibited the same trend with a marked peak in summer and the highest values when compared with site C4 (Schmidt et al. 2007). High short-lived radionuclide fluxes are the signature of a significant particle input within the last 100 days (Schmidt et al. 2002) whereas bioturbation rates are likely to vary with carbon organic fluxes (Smith et al. 1993; Trauth et al. 1997; Schmidt et al. 2001). The simultaneous occurrence of both signals may indicate that there is a high, rapid sedimentation of presumably carbon-rich particles occurring at site C5, mainly in summer. Previous works reported that oyster cultivation produces biodeposits enhancing benthic activity (Kautsky and Evan 1987; Chapelle et al. 2000). We hypothesized that this biodeposition accounts for the high bioturbation rates and radionuclide fluxes at site $\mathrm{C} 5$. Biodeposition is therefore a parameter that could influence locally bioturbation in the Thau Lagoon.

\subsection{Benthic response to shellfish farming in the Thau lagoon}

The Thau lagoon is characterized by an ecosystem with a large biomass of filter feeders growing in waters with high residence time due to low tides. The influence of shellfish farming on the in situ water chemistry was already established and proved significant during all seasons (Chapelle 2000; Souchu et al. 2001).

The recently published special issue on biogeochemical and contaminant cycling in sediments of this basin (see introductive paper by Rabouille et al. 2007) provides additional aspects for the sediment compartment. Large differences are reported for the two contrasted sites $\mathrm{C} 5$ and $\mathrm{C} 4$. At station $\mathrm{C5}$, inside the shellfish farming zone, the concentration of particulate organic carbon (POC) was $6.7 \mathrm{wt} \%$ in the top sample, decreasing to $3 \mathrm{wt} \%$ in the bottom sample $(18 \mathrm{~cm})$. For site $\mathrm{C} 4$, in the middle of the lagoon, POC concentrations were around $4 \mathrm{wt} . \%$ in the top $4 \mathrm{~cm}$, below which the concentration remained generally between 3 and 4 wt $\%$ (Anschutz et al. 2007); this organic matter seems to be much more refractory, as already postulated from radionuclides and granulometry data. 
The oyster-driven biodeposition was shown through higher values of particulate and dissolved organic carbon at the surface water interface at C5 compared to C4 (Anchutz et al. 2007). Not surprisingly, organism counting and identification highlight characteristic populations of organic rich sediments in station C5 (Duport et al. 2007).

This organic enrichment linked to oyster farming was clearly visible on oxygen distributions and fluxes and led to an increased intensity of diagenesis (Dedieu et al. 2007; Metzger et al. 2007; Thouzeau et al. 2007). Oxygen profiles penetrated twice as much at the central site compared to the organically enriched one (Dedieu et al. 2007). The annual averages (2002-2003) of seasonal the diffusive oxygen uptake values were, however, about three times greater at C5 (37$\left.88 \mathrm{mmol} \mathrm{m}^{-2} \mathrm{~d}^{-1}\right)$ compared to $\mathrm{C} 4\left(9-31 \mathrm{mmol} \mathrm{m}^{-2} \mathrm{~d}^{-1}\right)$ (Thouzeau et al. 2007); sulphate reduction rates also differed in the same proportion as the oxygen fluxes (Point et al. 2007).

In summary, site C5 presents consistent signals of a large diversity of parameters (radionuclides, oxygen profiles and fluxes, dissolved species, organic matter) demonstrating a significant impact of intensive oyster farming, through biodeposition in particular, on underlying sediments. Megter et al. (2007) concluded shellfish farming has physical implications as well as biological and diagenetic effects, both of which favor anoxia crises ("malaïgues").

\section{Conclusion}

This investigation provides insight into seasonal variations of bioturbation on a coastal lagoon under high anthropogenic pressure. Time-series of ${ }^{234} \mathrm{Th}$ and ${ }^{7} \mathrm{Be}$ allowed to establish a comprehensive and robust picture of the bioturbation at the water-sediment interface of the Thau Lagoon; these two shortlived tracers being particularly appropriate to coastal systems, where usually ${ }^{210} \mathrm{~Pb}$ presents a mixed layer. Both ${ }^{234} \mathrm{Th}$ and ${ }^{7} \mathrm{Be}$ registered seasonal variations in activities and in penetration within the sediment, indicating significant changes in mixing intensity; From the controlling factors usually proposed, food supply, mainly driven by hydrodynamic, appears the most relevant to explain spatial and seasonal variability of bioturbation in the Thau Lagoon. Locally shellfish production has a direct positive impact on sediment mixing via the biodeposition. A synthesis of recently published data set (oxygen consumption, organic carbon content, distribution of dissolved species) corroborates this conclusion, indicating a large impact of shellfish farming on both the sediment and the overlying water.

These are important implications of the bioturbation inferred in the sediment of the Thau Lagoon. Indeed seasonal variations in the deep mixing of sediment, to depths up to 8 $\mathrm{cm}$, must have profound effects on the re-distribution of recently deposited contaminants and on redox conditions in the sediments. Therefore, we suggest future works on bioturbation to better understand the interaction between sediment reworking and biological-biogeochemical processes. This knowledge may help to evaluate the impact of shellfish farming on the cycling of matter and contaminants in the Thau lagoon.
Acknowledgements. This paper belongs to a PNEC series of articles published in Aquatic Living Resources Vol. 20, No. 1, 2007. This work is supported by the PNEC-ART1 MICROBENT, the PNEC Chantier Lagunes méditerranéennes and the ACI ARTTE programmes, the CNRS, the University of Bordeaux I. We are grateful to the IFREMER diving team for their skilled work on the field, to J-L. Guillou as crew of the "Chlamys" and to J. Tronczyñski team for sediment sampling in May, 2004. Data of ${ }^{234} \mathrm{Th}$ in excess and ${ }^{7} \mathrm{Be}$ are available on request. The authors thank the IFREMER-Sète for logistic support through lab space and research boat. This is EPOC and Nereis Park contributions $\mathrm{n}^{\circ} \mathrm{xx}$.

\section{References}

Aller R.C., Cochran J.K., 1976, ${ }^{234} \mathrm{Th} /{ }^{238} \mathrm{U}$ disequilibrium in nearshore sediment: particle reworking and diagenetic timescales. Earth Planet. Sci. Lett. 29, 37-50.

Anschutz P., Chaillou G., Lecroart P., 2007, Phosphorus diagenesis in sediment of the Thau Lagoon. Estuar. Coas. Shelf Sci. 72, 447456.

Boudreau B.P., 1986, Mathematics of tracer mixing in sediments: I. Spatially-dependent, diffusive mixing. Am. J. Sci. 286, 161-198.

Chapelle A., Menesguen A., Deslous-Paoli J.M., Souchu P., Mazouni N., Vaquer A., Millet B., 2000, Modelling nitrogen, primary production and oxygen in a mediterranean lagoon. Impact of oysters farming and inputs from the watershed. Ecol. Model. 127, 161181.

Crusius J., Bothnera M.H., Sommerfield C.K., 2004, Bioturbation depths, rates and processes in Massachusetts Bay sediments inferred from modeling of ${ }^{210} \mathrm{~Pb}$ and ${ }^{239+240} \mathrm{Pu}$ profiles. Estuar. Coast. Shelf Sci. 61, 643-655.

Demopoulos A.W.J., Smith C.R., DeMaster D.J., Fornes W.L., 2003, Evaluation of excess ${ }^{234} \mathrm{Th}$ activity in sediments as an indicator of food quality for deep-sea deposit feeders. J. Mar. Res. 61, 267284.

DeMaster D.J., Pope R.H., Levin L.A., Blair N.E., 1994, Biological mixing intensity and rates of organic carbon accumulation in North Carolina slope sediments. Deep-Sea Res. II 41, 735-753.

Dedieu K., Rabouille C., Thouzeau G., Jean F., Chauvaud L., Clavier J., Mesnage V., Ogier S., 2007, Benthic $\mathrm{O}_{2}$ distribution and dynamics in a Mediterranean lagoon (Thau, France): An in situ microelectrode study. Estuar. Coast. Shelf Sci. 72, 393-405.

Duport E., Gilbert F., Poggiale J.-C., Stora G., 2007, Macrofauna and sediment reworking quantification at the Thau Lagoon. Estuar. Coast. Shelf Sci. 72.

Dupuy C., Vaquer A., Lam-Höai T., Rougier C., Mazouni N., Lautier J., Collos Y., Le Gall S., 2000, Feeding rate of the oyster Crassostrea gigas in a natural planktonic community of the Mediterranean Thau Lagoon. Mar. Ecol. Prog. Ser. 205, 171-184.

Fuller C.C., van Geen A., Baskaran M., Anima R., 1999, Sediment chronology in San Francisco Bay, California, defined by ${ }^{210} \mathrm{~Pb}$, ${ }^{234} \mathrm{Th},{ }^{137} \mathrm{Cs}$ and ${ }^{239,240} \mathrm{Pu}$. Mar. Chem. 64, 7-27.

Gangnery A., Bacher C., Buestel D., 2001, Assessing the production and the impact of cultivated oysters in the Thau lagoon (Méditerranée, France) with a population dynamics model. Can. J. Fish. Aquat. Sci. 58, 1012-1020.

Kautsky N., Evan S., 1987, Role of biodeposition by Mytilus edulis in the circulation of matter ad nutrients in a Baltic coastal ecosystem. Mar. Ecol. Prog. Ser. 38, 201-212.

Labonne M., Othman D.B., Luck J.-M., 2001, Pb isotopes in mussels as tracers of metal sources and water movements on a lagoon (Thau Basin, S. France). Chem. Geol. 181, 181-191. 
Lecroart P., Schmidt S., Jouanneau J.-M., 2007a, Numerical estimation of the error of the biodiffusion coefficient in coastal sediments. Estuar. Coast. Shelf Sci. 72, 543-552.

Lecroart P., Schmidt S., Anschutz P., Jouanneau J.-M., 2007b, Modeling sensivity of biodiffusion coefficient to seasonal bioturbation. J. Mar. Res. 65, in press.

Maire O., Duchêne J.-C., Rosenberg R., Braga de Mendonça Jr. J., Grémare A., 2006, Effects of food availability on sediment reworking in Abra ovata and A. nitida. Mar. Ecol. Prog. Ser. 319, 135-153.

Metzger E., Simonucci C., Viollier E., Sarazin G., Prévot F., Jézéquel D., 2007, Benthic response to shellfish farming in Thau lagoon: Pore water signature. Estuar. Coast. Shelf Sci. 72, 406-419.

Monna F., Lancelot J., Bernat M., Mercadier H., 1997, Taux de sédimentation dans l'étang de Thau à partir des données géochronologiques, géochimiques et des repères stratigraphiques. Oceanol. Acta 20, 627-638.

Plus M., Chapelle A., Lazure P., Auby I., Levavasseur G., Verlaque M., Belsher T., Deslous-Paoli J.-M., Zaldívar J.-M., Murray C.N., 2003, Modelling of oxygen and nitrogen cycling as a function of macrophyte community in the Thau lagoon. Cont. Shelf Res. 23, 1877-1898.

Point D., Monperrus M., Tessier E., Amouroux D., Chauvaud L., Thouzeau G., Jean F., Amice E., Grall J., Leynaert A., Clavier J., Donard O.F.X., 2007, Biological control of trace metal and organometal benthic fluxes in a eutrophic lagoon (Thau Lagoon, Mediterranean Sea, France). Estuar. Coast. Shelf Sci. 72, 457471.

Rabouille C., Amouroux D., Anschutz P., Jouanneau J.-M., Gilbert F., Cossa D., Prevot F., 2007, Biogeochemical and contaminant cycling in sediments from a human-impacted coastal lagoon - Introduction and summary. Estuar. Coast. Shelf Sci. 72, 387-392.

Reed D.C., Huang K., Boudreau B.P., Meysman F.J.R., 2006, Steadystate tracer dynamics in a lattice-automaton model of bioturbation. Geochim. Cosmochim. Acta 70, 5855-5867.
Schmidt S., Reyss J.-L., 2000, Improvement in radiochemical and $\gamma$-counting procedures for the determination of ${ }^{234} \mathrm{Th}$ in seawater. Radiochim. Acta 88, 459-463.

Schmidt S., de Stigter H.C., van Weering Tj.C.E., 2001, Enhanced short-term sediment deposition within the Nazare Canyon, NorthEast Atlantic. Mar. Geol. 173, 55-67.

Schmidt S., van Weering Tj.C.E., Reyss J.-L., van Beek P., 2002, Seasonal deposition and reworking at the sediment-water interface on the north-western Iberian Margin. Prog. Oceanogr. 52, 331-348.

Schmidt S., Jouanneau J-M., Weber O., Lecroart P., Radakovitch O., Gilbert F., Jezequel D., 2007, Sedimentary processes in the Thau Lagoon (South France): from seasonal to century time scales. Estuar. Coast. Shelf Sci. 72, 534-542.

Smith C.R., Rabouille C., 2002, What control the mixed layer in deep ocean sediments? the importance of POC flux. Limnol. Oceanogr. $47,418-426$.

Souchu S., Vaquer A., Collos Y., Landrein S., Deslous-Paoli J.-M., Bibent B., 2001, Influence of shellfish farming activities on the biogeochemical composition of the water column in Thau lagoon. Mar. Ecol. Prog. Ser. 218, 141-152.

Thouzeau G., Grall J., Clavier J., Chauvaud L., Jean F., Leynaert A., ni Longphuirt S., Erwan Amice E., Amouroux A., 2007, Spatial and temporal variability of benthic biogeochemical fluxes associated with macrophytic and macrofaunal distributions in the Thau lagoon (France). Estuar. Coast. Shelf Sci. 72, 432-446.

Trauth M.H., Sarnthein M., Arnold M., 1997, Bioturbidational mixing depth and carbon flux at the seafloor. Palaeogeogr., Palaeoclim. Palaeoecol. 12, 517-526.

Wheatcroft R.A., 2006, Time-series measurements of macrobenthos abundance and sediment bioturbation intensity on a flooddominated shelf. Prog. Oceanogr. 71, 88-122.

Widdows J., Blauw A., Heip C.H.R., Herman P.M.J., Lucas C.H., Middelburg J.J., Schmidt S., Brinsley M.D., Twisk F., Verbeek H., 2004, Role of physical and biological processes in sediment dynamics. Mar. Ecol. Prog. Ser. 274, 41-56. 